\title{
The Impact of Culture on Instructional Design and Quality
}

\author{
Afsaneh Sharif \\ $\mathrm{PhD}$, Centre for Teaching, Learning and Technology, University of British Columbia, \\ Canada, Afsaneh.sharif@ubc.ca

\section{Merce Gisbert} \\ Prof., Department of Pedagogy University Rovira i Virgili, Spain, \\ merce.gisbert@urv.cat
}

The purpose of this study was to investigate the effect of cultural differences, i.e. different contexts and backgrounds, on instructional designers' perspectives of quality in online environments. Using a questionnaire developed based on the Quality Matters rubric, we found designers in Canada focus slightly more on Learner Support strategies than designers in Spain. Despite differences in their contexts and some responsibilities, instructional designers in both countries consider the same features important and pay attention to them in their practices in order to develop good quality online courses. These features are institutional commitment, faculty support, student support, technology, course structure/instructional design, and assessment/evaluation and accessibility. Future research is required to improve the generalization of the results of the existing study while identifying other factors, such as budget and technology literacy that influence instructional designers' approaches in developing high-quality online learning materials.

Keywords: Online learning, quality, instructional design, cultural differences, instructional designer, online environments

\section{INTRODUCTION}

Instructional design is a profession that has yet to be fully recognized by educators. Professionals who perform instructional design tasks have neither the same title nor the same pay scale across countries and at times even within the same organization. These titles include Instructor, Course Developer, Curriculum Developer, Educational Technology Specialist, Program Consultant, and Learning Designer (Gibby et al., 2002). In some countries, such as Canada, the position is well established and has been recognized for more than a decade; in other countries, such as Spain, because of the popularity of online learning instructional design has recently acquired social recognition. In Canada, many professionals work under the title of Instructional Designer and are mostly located within a service unit of their organizations. In Spain, the majority of instructors consider themselves as instructional designers, and the 
position under the title of Instructional Designer has recently started to take shape. As we witness a greater inclination towards online learning, concerns about the quality of online learning and the practice of key professionals in online course development are on the rise amongst educators. Many educators have argued that online learning can effectively respond to accelerating global competition to increase the quality of learning experiences, to remove situational barriers including time and space, and to be more cost effective (Daniel, 1996; Garrison \& Anderson, 2003; Twigg, 2003; Bates, 2005). Many guidelines and benchmarks have been developed for quality of online learning programs; Sir John Daniel, along with other experts from different institutions, has recently listed many of these in a guide, which is licensed under the Creative Commons (Daniel, 2013). The emphasis of guidelines may differ, but the common aspects of quality for online programs can be easily identified as institutional commitment, faculty support, student support, technology, course structure/instructional design, and assessment/evaluation.

Instructional designers play a key role in an online course development process. While there are many instructional design models and guidelines in place, the constant change in the field of instructional design calls for instructional designers to be dynamic agents of change who use design thinking to navigate the design options and develop online courses. Many educators argue that there has been a shift from the role's reliance on models to govern the design process to positioning it as the central source of design, which emerges from personal judgement and experience. Tracey, Hutchinson, and Quinn Grzebyk (2014) consider that instructional designers "are active and reflective agents of innovation whose storehouse of design precedents feeds professional judgement and action in the design space" (p. 316).

This study examines the quality of online learning through the perspectives of instructional designers in different countries. Through a survey based on the Quality Matters rubric and conducted in 2012 for instructional designers in British Columbia (BC) in Canada, it was found that all designers have similar perspectives on quality of online courses. They focus on the same elements, such as assessment and course overview, and find the same elements critical in their design. To investigate whether culture has any impact on instructional designers' perspectives for designing a quality online course, we used exactly the same survey in a Spanish context.

\section{Brief Literature Review}

A variety of scholars, educators, organizations, and accrediting agencies have developed guidelines, standards, rubrics, and frameworks for assuring the quality of online learning (Barker, 2002; Bourne \& Moore 2004; Blood-Siegfried et al., 2008; Quality Matters Program, 2011). All these guidelines and publications include similar criteria for online education, which include strong institutional commitment, adequate curriculum and instruction, peer review, effectiveness, faculty-to-student ratios, attrition rates, student support, sufficient faculty support, instructional design, technology appropriateness, accessibility, and consistent learning outcome assessment (Chao, Saj, \& Tessier, 2006; Corry, 2008; Little, 2009; Wang, 2006). Quality assurance can be seen through different lenses and affected by different views such as those of administrators, designers, 
instructors, students, and program leaders; in this paper we focus on instructional designers' perspectives.

Instructional design includes all the processes involved in optimizing learning and performance (Reiser, 2001). Instructional design, from a process perspective, is a set of activities with the goal of optimising learning experiences to achieve specific objectives. From a learning perspective, it is a branch of knowledge concerned with translating general principles of learning into plans for instructional materials and learning. With the increasing use of Internet for learning, ID has come to be associated mostly with technology-based learning. Online instructional design is the applied study of effective planning, design, and delivery of information, materials, and objectives to students, integrating an assessment of the student's learning results, with a view towards perfecting the online learning experience and process (Carbonell, 2012). Instructional designers, in one of the key roles in the course development process, take on different titles in different parts of the world. Richey, Fields, and Foxon (2001) specify four roles for an instructional designer: analyst, evaluator, e-learning specialist, and project manager. In recent years the position has been referred to as an "agent of social change" and "civic-minded professionals" (Schwier et al., 2006; Yusop \& Correia, 2012). The ongoing shifts and evolution of the instructional design field force instructional designers to constantly adapt and evolve with it. There are many factors that affect instructional design work; culture is one of them.

Many contemporary definitions of culture explain culture as a system of knowledge (Spencer-Qatey, 2012; Gudykunst \& Kim, 2003), and others define it as problem solving in a sense that culture affects people's behavior and people can find guidance in their culture on how to handle and solve problems (Lustig \& Koester, 2012; SpencerOatey, 2008, 2012). Culture includes knowledge, belief, art, morals, law, custom, and any other capabilities and habits acquired by someone as a member of society (SpencerQatey, 2012). In response to understanding culture in the context of instructional design, it is important to note that "culture in education goes beyond the idea of training and effective practices of teaching and learning" (Grant, 2013). It includes the very presence of who we are, what we know, and how we learn. When we teach, we are teaching culture, including its manifestos of knowledge, skills, and attitudes. This way, we can come to understand education as being a process that is fundamentally sociocultural in nature (Thomas, 2003). Recent studies determined that instructional design does not exist outside of a consideration of culture; culture is an important value for educators to hold because they are in the position of social agents having significant influence on their learners (Grant, 2013; Schwier, Campbell, \& Kenny, 2004). Kinuthia (2009) claims culture influences instruction at several levels, including institutional, instructional content, instructors, and learners.

Due to the constant evolution of online learning and internationalization and accessibility of online learning (i.e., Massive Open Online courses), consideration of cultural and social differences among students and between providers and learners has become a greater issue for the success of the online program. Figure 1 demonstrates how our instruction is affected by the culture surrounding it at different levels. Grant (2013, 
p. 30) explains how Collis (1999) outlined the ways cultural variables interact and influence each other on four levels: societal, personal, organizational, and disciplinary. He continues with the premise that the combinations of social and cultural factors are closely related to those of learning processes and promoting knowledge acquisition for students, as shown in Figure 1, and also to the development of courses and materials in delivering culturally sensitive instruction. Figure 1 also demonstrates the Cultural Dimension of Learning Framework proposed by Parrish and Linder-VanBerschot (2010), which is a set of cultural parameters regarding epistemological beliefs, social relationships, and temporal perceptions that are most likely to impact instructional situations.

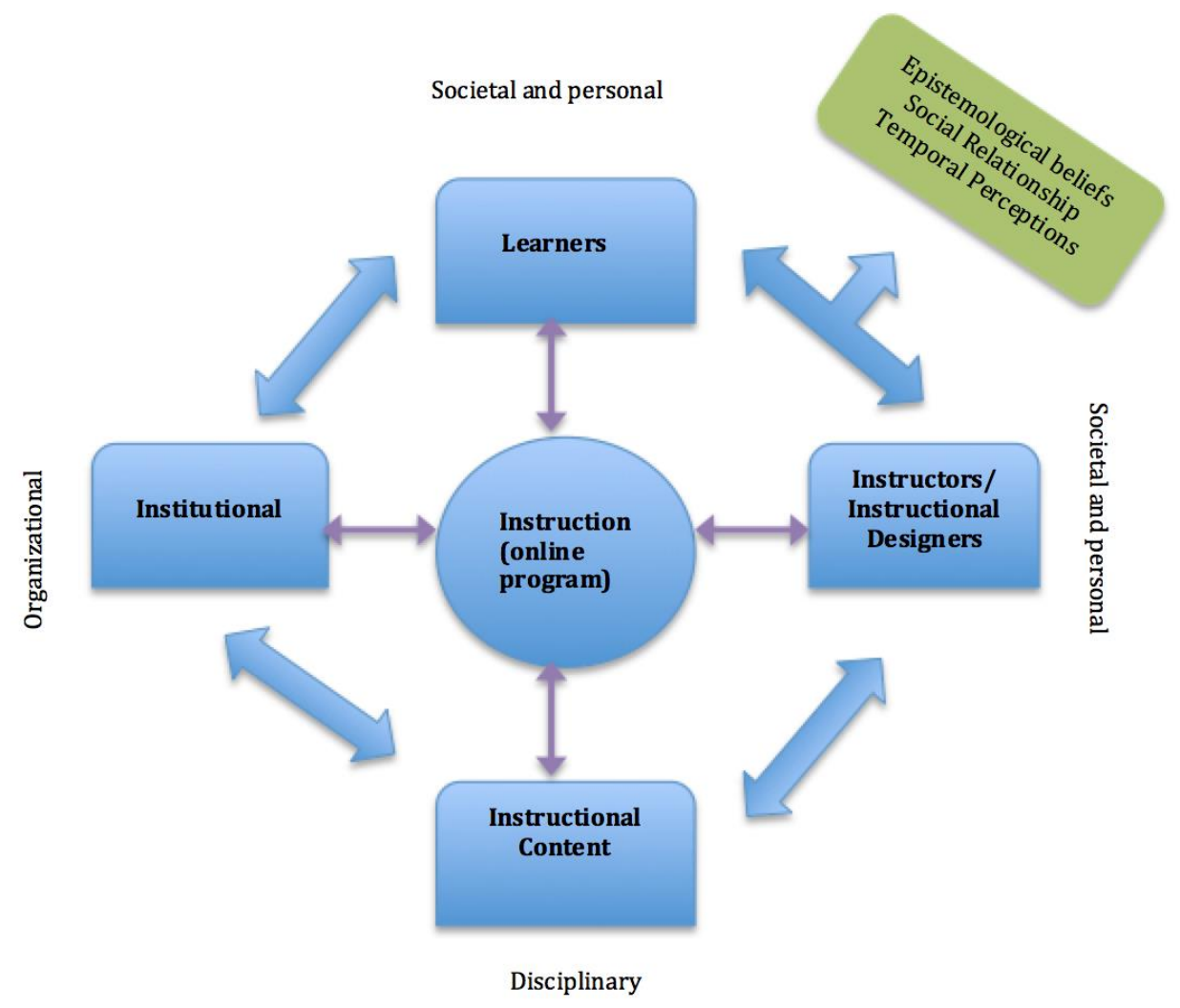

Figure 1: Impact of culture on instruction and instructional designer's work

When designing courses, instructional designers make both implicit and explicit decisions. As per Hando and Ahern (2012), explicit design decisions are those we learn to make consciously, such as creating learning objectives. Implicit design decisions are mostly based on personal assumptions and preferences, such as type and frequency of

International Journal of Instruction, January $2015 \bullet$ Vol.8, No.1 
interactions that should take place in a course. Cultural background may show its impact in implicit designs more than explicit. For example, in many Asian and Middle Eastern countries, designers may lean toward note taking in class rather than discussions and a constructivist approach, since these concepts are not well introduced in their education systems and cultures. The instructor is still seen as the source of knowledge and should not be questioned. In North America, designers may be hesitant to use/introduce group activities, since students are not comfortable working in groups and there are always some complaints from students saying "He/she didn't contribute to the project". Also, designers in North America might want to involve learners in knowledge/resource/content building, whereas designers from other parts such as Iran and China might want to provide all the content ready for learners because they consider that students pay to learn and should get all the resources and information necessary. Our culture and the cultures of our target learners might affect our design approaches and decisions; however, our core values, skills, and common sense might stay intact when it comes to a quality design.

In this study, we will explore whether differences in context, countries, and implicit decisions affect instructional designers' perspectives on key elements of a quality course. These key elements are presented within eight categories and include course overview and introduction, learning objectives, assessment, instructional materials, learner interaction, course technology, learner support, and accessibility. By examining how culture and cultural differences interact with the design process and impact instructional designers' work/perspective, we try to improve our understanding of the socio-cultural issues in instructional design foundations and so get closer to key elements for a quality online program.

\section{METHOD}

The main goal of this study was to gain an understanding of how key elements of a quality online course guideline are perceived and pursued by instructional designers in different contexts and countries.

\section{Study Setting and Context}

In this study, participants were purposefully selected based on their work experience with instructional design and online course development. In both countries participants consider themselves instructional designers whether they carried the job title or not. In the Canadian context, there were 33 participants, of whom more than $80 \%$ were instructional designers from public post-secondary schools. The survey was distributed at the Just Instructional Design (Just ID) event in June 2012. Just ID takes place in British Columbia, Canada each year and welcomes all instructional designers in public schools as well as educators involved in the instructional design process from private companies in British Columbia. Most of the participants are from post-secondary schools. The event is informal and is aimed to be a session where instructional designers can exchange ideas, share best practices, discuss design challenges, and network. In the Canadian context, in the majority of public schools, the profession of the instructional designer exists not only under the title of instructional designers but also under other 
titles, such as learning designer, education technology specialist, and curriculum consultant, to support instructors and faculty to improve their learning environments or teaching practices.

In the Spanish context, there were 19 participants, all from public post-secondary schools. In Spain the survey was distributed by emails to the research group and instructors who do not work under the title of "Instructional Designer" yet consider themselves instructional designers working on and teaching their courses. The participants are from four different universities in Spain: Universitat Rovira i Virgili (URV), Universidad de Murcia, Universidad de les Illes Balears, and Universidad d'Alacant. In the Spanish context, there is no official position of Instructional Designer; however, considering tasks and responsibilities that instructional designers are involved in, all instructors who have collaborated in the study do the same tasks as instructional designers in addition to their teaching and research.

All the participants in the study were asked to fill out the same rubric (see Appendix A), which is based on the Quality Matters rubric standards 2011-2013 edition. The rubric covers key areas of course quality under eight categories: course overview, learning objectives, assessment, instructional materials, learner interaction, course technology, learner support, and accessibility. Two columns were added to the rubric to gather information from instructional designers regarding their course development practices. The purpose of the rubric was to gather information on how instructional designers from different countries rate each key element of a quality course design in their practice. The instrument was distributed and validated by a few instructional designers from the same group in each country and was modified and finalized based on their feedback and agreement. The two columns were labelled based on the required data, and the rubric was finalized based on feedback received from both groups. The participants were asked to rate each point in the rubric under two categories, importance and focus. The "focus" column is to find out how much the designers actually pay attention and focus on these elements when they design a course. The "importance" column is to gather information on how important designers find each point in the rubric in their course development process. The same instrument was used for both groups.

\section{FINDINGS}

Survey results show that designers in Canada focus more on learner support strategies than designers in Spain. For example, only one Spanish designer in comparison with nine Canadian designers "always" focuses on ensuring that course instructions articulate or link to the institution's accessibility policies and services. This difference might be due to cultural differences or other factors such as budget, resources, training, and institutions' commitments. In another element, again only one Spanish designer as compared with nine Canadian designers always focuses on ensuring course instructions articulate or link to an explanation of how the institution's academic support services and resources can help students succeed in the course and how students can access the services. This might be related to the fact that the Spanish designers' institutions may not have such a support service or designers are not aware of such a service. It can also be related to designers' beliefs concerning how useful they find such services for 
learners. Table 1 shows all the elements of learner support and how designers in each country rated them.

Figures 2 and 3 show the average ratings of designers in each category in Canada and Spain.

Table 1: Learner Support Ratings in Spain and Canada

\begin{tabular}{|c|c|c|c|c|c|c|c|c|c|c|c|c|}
\hline \multirow[b]{2}{*}{ Learner Support Category } & \multicolumn{6}{|c|}{ Spanish Designers' Focus } & \multicolumn{3}{|c|}{$\begin{array}{l}\text { Canadian } \\
\text { Focus }\end{array}$} & \multicolumn{3}{|c|}{ Designers' } \\
\hline & 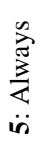 & $\begin{array}{l}\stackrel{ \pm}{\mathscr{D}} \\
\ddot{0}\end{array}$ & 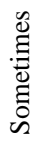 & 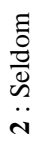 & $\begin{array}{l}\dot{\bar{d}} \\
\stackrel{\vec{J}}{Z} \\
\ddot{\sim}\end{array}$ & $\overleftrightarrow{Z}$ & $\begin{array}{l}\underset{\pi}{\infty} \\
\frac{\pi}{2} \\
\ddot{n}\end{array}$ & 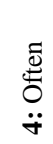 & $\begin{array}{l}\stackrel{\mathscr{\Xi}}{\Xi} \\
\stackrel{\Xi}{\Xi} \\
\vdots \\
\tilde{O}\end{array}$ & $\begin{array}{l}\frac{\Xi}{0} \\
\frac{0}{0} \\
\ddot{N} \\
\ddot{N}\end{array}$ & $\begin{array}{l}\dot{0} \\
\stackrel{\Delta}{Z} \\
\ddot{\sim}\end{array}$ & 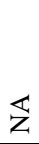 \\
\hline $\begin{array}{l}\text { The course instructions articulate or link to a } \\
\text { clear description of the technical support } \\
\text { offered and how to access it. }\end{array}$ & 4 & 6 & 3 & 5 & & 1 & 18 & 7 & 6 & 2 & & \\
\hline $\begin{array}{l}\text { Course instructions articulate or link to the } \\
\text { institution's accessibility policies and services. }\end{array}$ & 1 & 7 & 8 & 1 & & 1 & 9 & 8 & 10 & 5 & 1 & \\
\hline $\begin{array}{l}\text { Course instructions articulate or link to an } \\
\text { explanation of how the institution's academic } \\
\text { support services and resources can help } \\
\text { students succeed in the course and how } \\
\text { students can access the services. }\end{array}$ & 1 & 6 & 5 & 4 & 1 & 2 & 9 & 11 & 7 & 3 & 3 & \\
\hline $\begin{array}{l}\text { Course instructions articulate or link to an } \\
\text { explanation of how the institution's student } \\
\text { support services can help students succeed and } \\
\text { how students can access the services. }\end{array}$ & 1 & 5 & 5 & 4 & 1 & 2 & 8 & 6 & 12 & 4 & 3 & \\
\hline
\end{tabular}




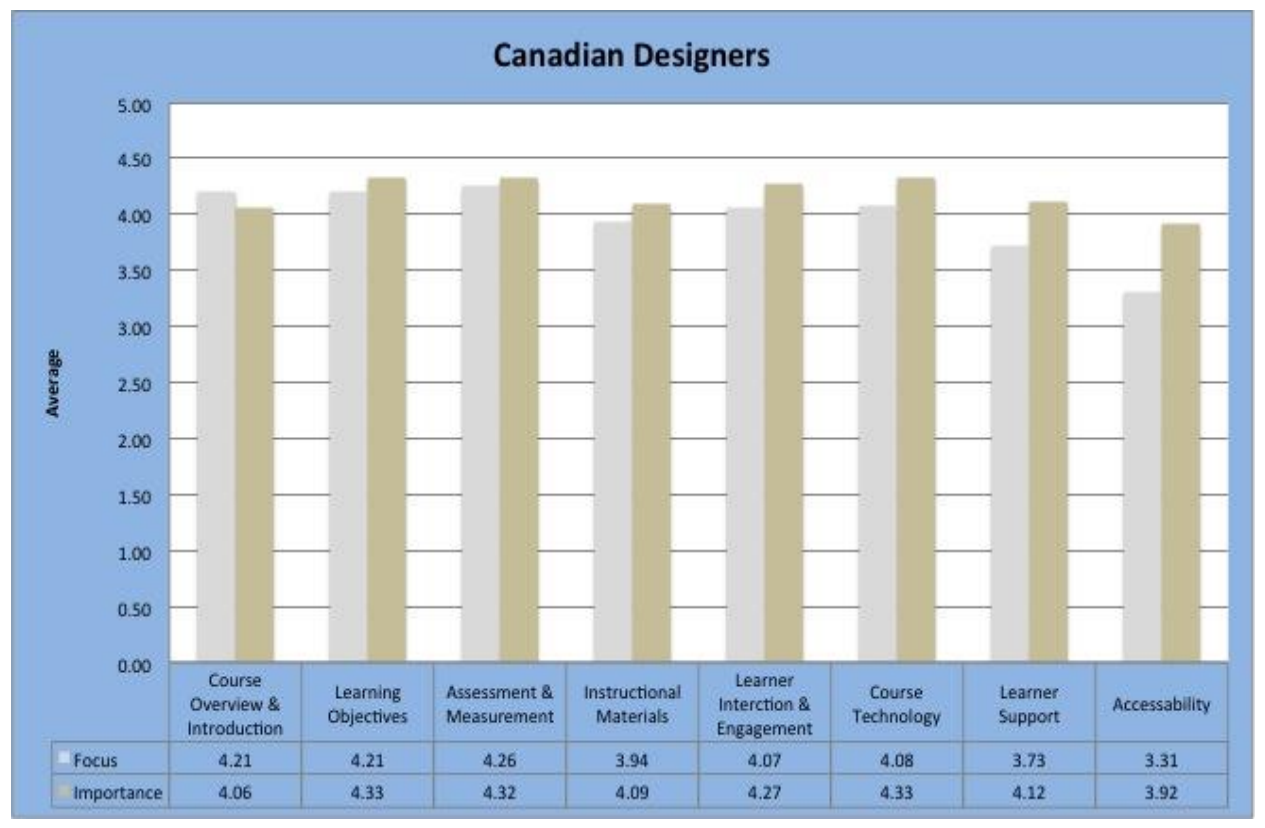

Figure 2: Canadian designers' average

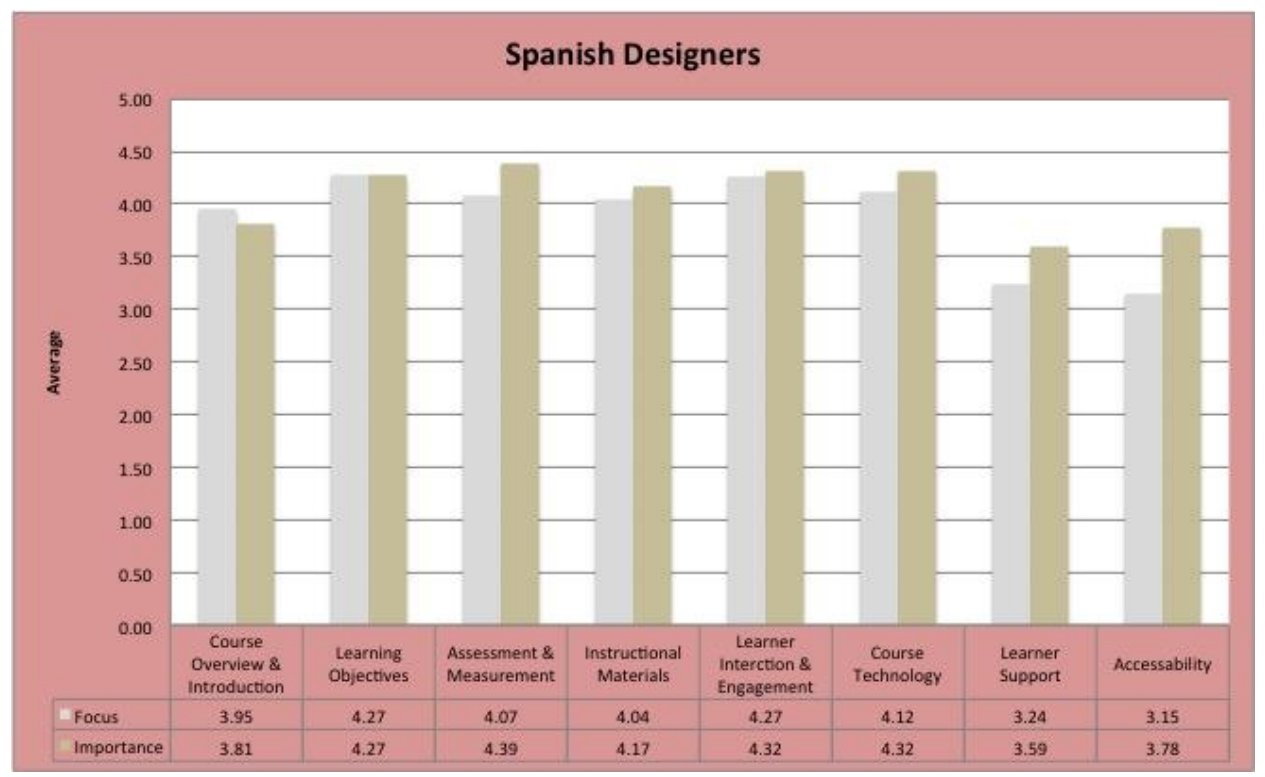

Figure 3: Spanish designers' average

International Journal of Instruction, January $2015 \bullet$ Vol.8, No.1 
In all the categories shown above, designers from both countries consider the elements important and focus on them in their practice. In comparing their averages in Focus (see Figure 4) the average rating is given on a scale of 1 to 5 , where 5 means "Always the focus" and 1 means "Never the focus" of designers for each key area of course quality listed on the $x$ axis. As shown below, the averages were close in all the categories, with a slight difference noticeable in Learner Support.

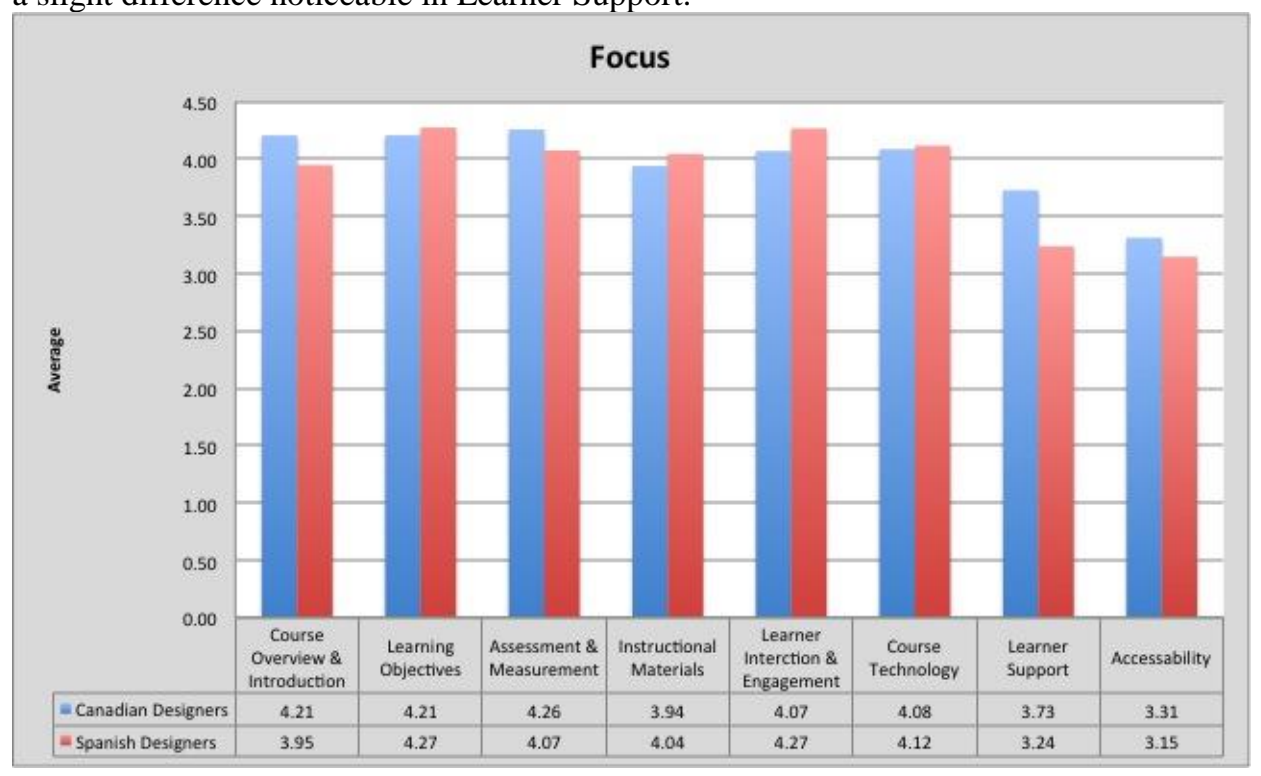

Figure 4: Comparison of BC and Spanish Designers' Rating

Overall, despite differences in their contexts and responsibilities, instructional designers in both countries consider the same elements as important and invest resources in them to ensure quality online courses.

\section{Research Limitations}

One limitation of the study is that while it is designed to highlight the key elements for quality of online programs and to identify the impact of cultural differences in importance of those elements, the instructional design field is quite large and the instructional designer positions so varied and different within the same culture let alone a different culture that it is impossible to explore all relevant topics. Another limitation is that designers are embedded within a bounded cultural context that affects both explicit and implicit design decisions. However, in design decisions it is hard to distinguish which decisions are directly affected by the designer's culture and to what extent. Also, in some cases it is hard to distinguish explicit design decisions from implicit ones. Feedback from this study can serve as a resource for decision making about existing and additional quality assurance rubrics and frameworks and the role of context/culture in a quality online program. 


\section{DISCUSSION AND CONCLUSION}

This study examined the quality of online learning through instructional designers' perspectives in different contexts and countries. Although there are publications on the topic of how our culture and background can impact our design, the results of this study show that these differences do not impact the designers' views on quality of online courses and the key elements. In this study, it was found that designers, despite differences in their contexts and responsibilities, in both Spain and Canada generally considered the same key elements of the guideline important and critical for a good quality course. Designers found all eight categories including proper course overview, alignment of learning objectives, assessment strategies, current instructional materials, effective learner interaction, proper use of course technology, learner support, and accessibility important for quality design. There was a slight difference among designers on how they focus on learner support in their work; designers in Spain were less focused on the learner support category in comparison with Canadian designers. This difference might have been caused by the designers' culture, institutional commitments, designers' beliefs, budget, technology, support, or other factors.

While there is significant existing literature on learner diversity/culture in instructional design and cultural issues in education, there are a limited number of texts focusing on the impact of culture on educators and how they design and teach. Obviously, when we design, we are not separated from our culture; our backgrounds, beliefs, values, and teaching and learning experiences are reflected in our design. Part of an instructional designer's identity is embedded in the context of the institutional culture in which ID is practiced (Schwier et al. 2004). However, there are many other factors that impact a designer's work and course development such as budget, time, institutional commitment and available resources.

Socio-cultural concepts are broad, and it is recognized that a single study is not enough to effectively cover all relevant issues. Further research is therefore important. Researchers can, for instance, conduct the same study in other countries and investigate whether the results are similar. Additionally, one particularly important possibility for research is further examination of the cultural aspects present within instructional design and practiced by instructional designers and to determine the impacts of these cultural aspects on the designers' work. The goal would be to help instructional designers create quality online courses/instruction that can help cross-cultural learners learn in ways that coincide with their culture, values, beliefs, and styles of learning. The courses designed with this approach would embrace the differences among learners and be enriched by the background diversity of the designer. The authors suggest that future research is required to improve the generalization of the existing study's results while identifying other factors, such as budget, institutional commitments and technology literacy that influence instructional designers' approach in developing high-quality online learning materials. 


\section{REFERENCES}

Barker, K. (2002). Canadian recommended e-learning guidelines. Retrieved January 20, 2012, from www.futured.com/pdf/CanREGs\%20Eng.pdf.

Bates, A. W. (2005). Technology, e-learning and distance education (2nd ed.). New York: Routledge Falmer Studies in Distance Education.

Blood-Siegfried, J. E., Short, N. M., Rapp, C. G., Hill, E., Talbert, S., Skinner, J., Campbell, A., \& Goodwin, L. (2008). A rubric for improving the quality of online courses. International Journal of Nursing Education Scholarship. 5(1), 1-13.

Bourne, J., \& Moore, J. C. (Eds.) (2004). Elements of quality online education: Into the mainstream. The Sloan-C Series, Vol. 5, The Sloan Consortium, Retrieved December 21, 2011, from sloanconsortium.org/publications/books/vol5summary.pdf

Carbonell, P. A. (2012). International mindfulness instructional design. Academic Research International, 3(1). Retrieved May 2014 from http://www.savap.org.pk/journals/ARInt./Vol.3(1)/2012(3.1-02).pdf

Chao, T., Saj, T., \& Tessier, F. (2006). Establishing a quality review for online courses. Educause Quarterly, 29(3), 32-39.

Collis, B. (1999). Designing for differences: Cultural issues in the design of WWWbased course-support sites. British Journal of Educational Technology, 30(3), 201-217.

Corry, M. (2008). Quality in distance learning. Distance Learning, 5(1), 88-91.

Daniel, Sir John (1996). Mega-universities and knowledge media: Technology strategies for higher education. London: Kogan Page.

Daniel, Sir John (2013). A guide to quality in online learning. Retrieved July 2013 from http://www.contactnorth.ca/tips-tools/guide-quality-online-learning.

Garrison, D. R., \& Anderson, T. (2003). E-learning in the $21^{\text {st }}$ century: A framework for research and practice. London: Routledge Falmer.

Gibby, S., Quiros, O., Demps, E., \& Liu, M. (2002). Challenges of being an instructional designer for new media development: A view from the practitioners. Journal of Educational Multimedia and Hypermedia, 11(3), 195-219.

Grant, J. (2013). Exploring the realm of culture within instructional design. Thesis, Department of Education, Concordia University. Montreal, Quebec, Canada.

Gudykunst, W. B., \& Kim, Y. Y. (2003). Communicating with strangers. An approach to intercultural communication. Boston: McGraw Hill.

Hando, A., \& Ahern, T. (2012). Hofstede's model of cultural dimensions: A tool for understanding how background culture affects instructional designers. In Proceedings of Society for Information Technology \& Teacher Education International Conference 2012, No. 1, pp. 1162-1170.

Kinuthia, W. (2009). Reflecting on embedding socio-cultural issues into instructional design. Multicultural Education \& Technology Journal, 3(4), 266-278. 
Little, B. B. (2009). Quality assurance for online nursing courses. Journal of Nursing Education. 48(7), 381-387.

Lustig, M. W., \& Koester, J. (2012). Intercultural competence: Interpersonal communication across cultures. NY, USA: HarperCollins.

Parrish, P., \& Linder-VanBerschot, J. A (2010). Cultural dimensions of learning: Addressing the challenges of multicultural instruction. International Review of Research in Open and Distance Learning, 10(2), 1-19. Retrieved February 2013 from http://www.irrodl.org/index.php/irrodl/article/view/809/1497.

Quality Matters Program. (2011). Quality matters rubric standards 2011-2013 edition. MarylandOnline. Retrieved November 22, 2012 from www.qmprogram.org/files/QM_Standards_2011-2013.pdf.

Reiser, R. A. (2001). A history of instructional design and technology. In R.A. Reiser and J.V. Dempsey (Eds.), Trends and Issues in Instructional Design and Technology. Englewood Cliffs: Prentice Hall College Division.

Richey, R. C., Fields, D. C., \& Foxon, M. (2001). Instructional design competencies: The standards (3rd ed.). Syracuse. NY: ERIC Clearinghouse.

Schwier, R. A., Campbell, K., \& Kenny, R. (2004). Instructional designer's observations about identity, communities of practice and change agency. Australasian Journal of Educational Technology, 20(1), 69-100.

Schwier, R., Hill, J., Wager, W., \& Spector, J. M. (2006). Where have we been and where are we going? Limiting and liberating forces in IDT. In M. Orey, J. McLendon, \& R. Branch (Eds.), Educational Media and Technology Yearbook. Westport, CT: Libraries Unlimited. pp. 75-96.

Spencer-Oatey, H. (2008). Culturally speaking. culture, Communication and Politeness Theory (2nd ed.). London: Continuum.

Spencer-Oatey, H. (2012). What is culture? A compilation of quotations. GlobalPAD Core Concepts. Retrieved December 2012 from http://www2.warwick.ac.uk/fac/soc/ al/globalpad/openhouse/interculturalskills/global_pad_-_what_is_culture.pdf.

Thomas, M. K. (2003). Designer's dilemmas: The tripartite responsibility of the instructional designer. TechTrends, 47(6), 34-39. Retrieved May 2013 from https://stjohns.digication.com/michael_k_thomas/Research_and_Conceptual_Articles.

Tracey, M. W., Hutchinson, A., \& Grzebyk, T. Q.(2014). Instructional designers as reflective practitioners: developing professonal identity through reflection. Educational Technology Research and Development, (2014). 62(3): 315-334. DOI 10.1007/s11423014-9334-9.

Twigg, C.A. (2003). Improving learning and reducing costs: New models for online learning. EDUCAUSE Review, 38(5), 29-38.

Wang, Q. (2006). Quality assurance-Best practices for assessing online programs. International Journal on E-Learning, 5, 265-274 
Yusop, D. F., \& Correia, A. (2012). The civic-minded instructional designers' framework: An alternative approach to contemporary instructional designers' education in higher education. British Journal of Educational Technology, 43(2), 180-190.

Comments: Thank you very much for your participation. If you are interested in this research or have any comments or questions, please contact Afsaneh Sharif at afsaneh.sharif@ubc.ca.

\section{Turkish Abstract}

\section{Öğretim Tasarımında ve Kalitesinde Kültürün Etkisi}

Bu çalışmanın amacı kültürel farklılıkların (farklı bağlamların ve geçmişlerin) online ortamlarda öğretim tasarımcılarının kaliteye yaklaşımları üzerindeki etkisini incelemektir. Quality Matters yönergesi temelli geliştirilen bir anket kullanarak Kanada'daki tasarımcıların Öğrenci Destek stratejileri üzerinde İspanya'daki tasarımcılardan biraz daha fazla yoğunlaştıkları bulunmuştur. Bağlamsal ve sorumluluk olarak farklılıklarına ragmen her iki ülkedeki tasarımcılar aynı özelliklerin önemli olduğunu düşünmüşler ve kaliteli bir online ders geliştirmek için aynı özellikleri dikkate almışlardır. Bu özellikler kurumsal bağlılık, iş arkadaşı desteği, öğrenci desteği, teknoloji, ders yapıs//ögretim tasarımı, ölçme/değerlendirme ve ulaşılabilirlik. Ödenek, teknoloji okur-yazarlığı gibi kaliteli online öğrenme materyali geliştirmede öğretim tasarımcılarının yaklaşımını etkileyen diğer faktörleri belirlerken, mevcut çalışmanın sonuçlarının genelleştirilmesini geliştirmek için gelecek çalışmaların yapılması gereklidir.

Anahtar Kelimeler: Online (çevrimiçi) öğrenme, Kalite, Öğretim tasarımı, Kültürel farklılıklar, Öğretim tasarımcısı, çevrimiçi ortamlar

\section{French Abstract}

\section{L'Impact de Culture sur Design D'instruction et Qualité}

Le but de cette étude était d'examiner l'effet de différences culturelles, c'est-à-dire des contextes différents et des contextes, sur les perspectives des concepteurs d'instruction de qualité dans des environnements en ligne. L'utilisation d'un questionnaire s'est développée basé sur la rubrique de Matières de Qualité, nous avons trouvé des concepteurs dans le centre de Canada légèrement plus sur des stratégies de Support d'Apprenant que des concepteurs en Espagne. Malgré des différences de leurs contextes et quelques responsabilités, des concepteurs d'instruction dans les deux pays considèrent les mêmes caractéristiques importantes et leur prêtent attention dans leurs pratiques pour développer des cours en ligne de bonne qualité. Ces caractéristiques sont l'engagement institutionnel, le support de faculté, le support d'étudiant, la technologie, le design de structure/d'instruction de cours et l'évaluation/évaluation et l'accessibilité. La recherche future est exigée pour améliorer la généralisation des résultats de l'étude existante en identifiant d'autres facteurs, comme l'alphabétisation budgétaire et technologique qui influence les approches des concepteurs d'instruction dans le développement de matériels d'apprentissage en ligne de haute qualité.

Mots-clés: Apprentissage en Ligne, Qualité, Design d'Instruction, Différences Culturelles, Concepteur d'Instruction, Environnements en Ligne 


\section{Arabic Abstract}

العنوان: تأثير الثقافة على التصميم التعليمي و الجودة.

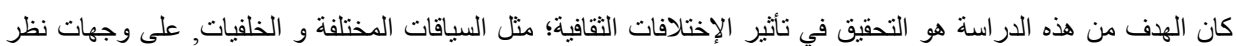

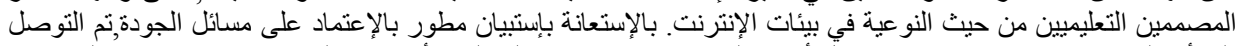

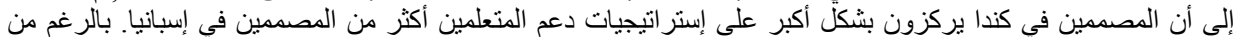

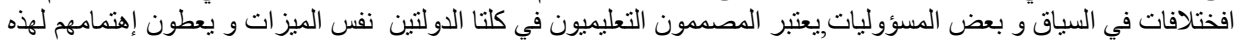

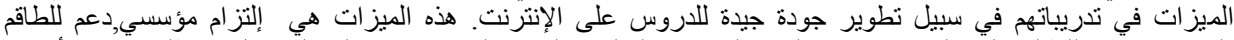

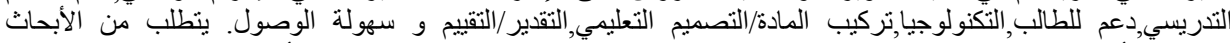

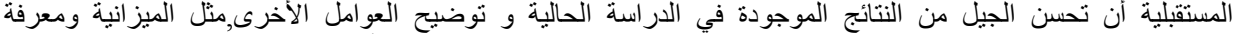

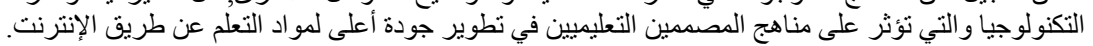

كلمات مهمة: التعلم عن طرق الإنترنت, الجودة,التصميم التعليمي, الإختلافات الثقافية, المصمم التعليمي,بيئات الإنترنت 